\title{
Accounting
}

\section{The empirical analysis of fiscal illusion}

\section{Nyayu Miftahul Ilmiyyah ${ }^{a^{*}}$, Yulia Saftiana ${ }^{a}$ and Tertiarto Wahyudi ${ }^{a}$}

${ }^{a}$ Accountancy, Economics Faculty, Sriwijaya University, Palembang-Prabumulih Street Km. 32, Indralaya, Ogan Ilir Regency, 30662, Indonesia

\begin{tabular}{l}
\hline C H R O N I C L E \\
\hline Article history: \\
Received May 152020 \\
Received in revised format May \\
162020 \\
Accepted July 62020 \\
Available online \\
July 152020 \\
\hline Keywords: \\
Fiscal Illusion \\
Local Government \\
Revenue Enhancement \\
Expenditure Manipulations \\
Debt Utilization
\end{tabular}

\section{A B S T R A C T}

This research aims to find the tendency fiscal illusion's existence in regencies/cities of South Sumatera Province during the period 2012 - 2018. In addition to detecting fiscal illusions, the study aims to determine the factors that explain the estimated value of detected fiscal illusions. To detect fiscal illusions, the study uses 3 approaches divided into 3 models, namely revenue enhancement, expenditure manipulations, and debt utilization. The sample of this research is 15 regencies/cities in South Sumatra Province. The analytical method used is panel data regression. The results of this study show that there was a fiscal illusion detected in regencies/cities of South Sumatera Province in the 2012-2018 period through the expenditure manipulation approach. Besides that, the test results also show that all variables in the expenditure manipulation approach affect and are able to explain the detected fiscal illusion.

\section{Introduction}

Indonesia as one of the most decentralized and democratic countries has committed to implement regional autonomy since 2001 (Hapsoro \& Yoduke, 2019). The enactment of regional autonomy turned out to have an impact on the emergence of fiscal illusions. The theory of fiscal illusion was first stated by an Italian economist, Amilcare Puviani, who described that fiscal illusion occurs when someone who plays a role in making decisions engineering / carrying out an illusion in finance that can cause other parties to judge and take wrong and improper actions (Puviani, 1976). Dollery and Worthington (1995); Adi and Ekaristi (2009) explained that the proportion of the Regional Budget and Expenditure (APBD) which is still dominated by general allocation funds (DAU) continues to increase, thus causing a high level of dependence on the central government without being accompanied by a significant increase in local own-source revenue (PAD). This phenomenon is stated as one form of indication of a fiscal illusion. Referring to the explanation, the fiscal illusion can be interpreted as asymmetric behavior of the regional government in responding to the transfer of central funds related to the optimization of regional autonomy. Provision of balancing funds in the form of DAU according to Nanga (2005) in Adi and Ekaristi (2009) apparently can create fiscal illusion. Local governments will tend to take advantage of the situation by increasing needs and trying to get funding from the central government to finance regional expenditure. The regions will get a smaller proportion of the balance funds when they have shown a significant increase in their financial capacity, so instead of trying hard to increase the ability and independence of the region through increased PAD, the regional government will try to obtain greater central government funding. Increasing PAD by utilizing available resources is the goal of implementing regional autonomy and decentralization (Hapsoro \& Yoduke, 2019). Law Number 23 Year 2014 states that taxes, retributions, and other valid PAD are the main components of PAD. DAU 
is a fund provided by the central government to overcome fiscal gaps and is intended to assist in the implementation of decentralization along with a special allocation fund (DAK), and a revenue sharing fund (DBH) provided. The successful implementation of regional autonomy can be seen through the level of regional financial capacity. Regional governments that have good fiscal capacity show that the region can be said to be capable of managing its regional finances, especially in managing and optimizing the acquisition of PAD (Islami, 2020). However, in reality what happened in Indonesia is that central government transfer funds have not been optimally prioritized for enhancing regional financial capacity but instead serve as the main source of funding. This can be seen in the diagram of the revenue composition of regencies / cities in Indonesia in 2018 in Fig. 1.

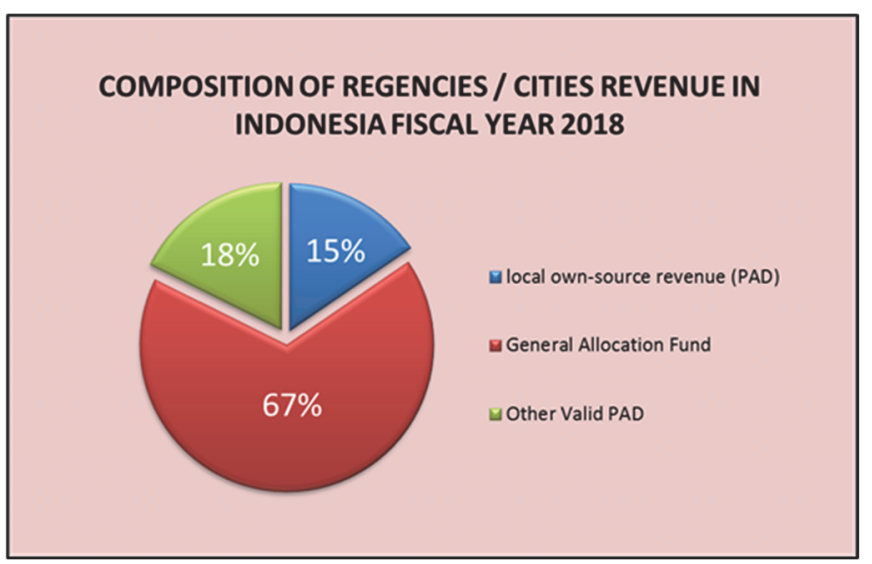

Fig.1. Composition of Regencies / Cities Revenue in Indonesia Fiscal Year 2018

(Source: Data processed 2020, Summary of APBD 2018 DJPK)

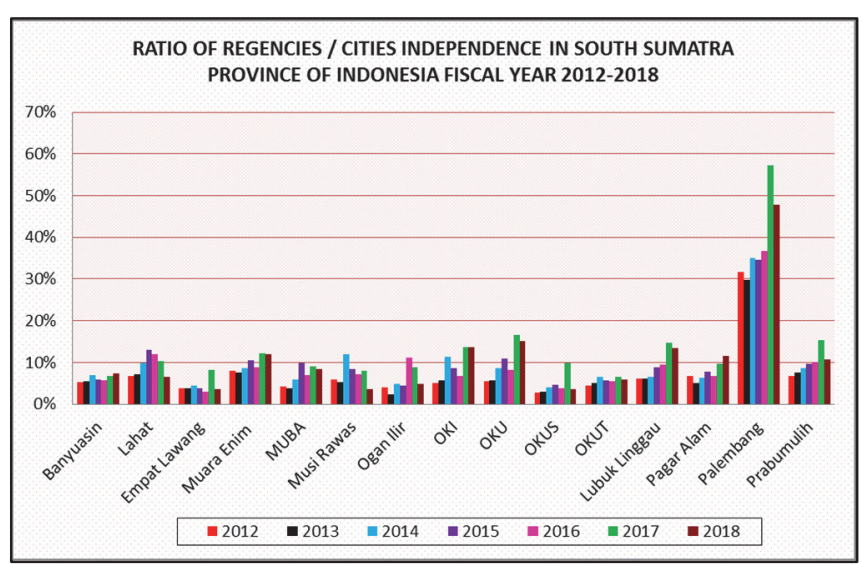

Fig. 2. Ratio of Regencies / Cities Independence in South Sumatra Province of Indonesia Fiscal Year 2012-2018 (Source : Data processed 2020, LHP BPK RI)

The diagram shows that $67 \%$ of total revenue is dominated by balancing funds. PAD only fills $15 \%$ of total regional income and the remaining $18 \%$ is filled by other legal income. The above description shows that there are still many regions in Indonesia, especially at the regencies / cities level that have not yet implemented regional autonomy to the fullest. South Sumatra with 17 regencies / cities through analysis of data obtained from BPK RI in 2012-2018 shows that the performance of the independence of the regencies / cities government in South Sumatra is still in the low category. This can be seen in Fig. 2. That figure shows the performance of financial independence that is not yet optimal, especially in the implementation of regional autonomy. During the 2012-2018 period, only Palembang City in 2017 had a level of independence reaching $57 \%$ but get decrease to $48 \%$ in 2018 . Meanwhile, the lowest was Ogan Ilir Regency (OI) in 2013 which was $2 \%$. So it can be concluded that the performance of the independence of regencies / cities of South Sumatra Province in 2012-2018 is still low. This phenomenon indicates the existence of fiscal illusions in regencies / cities in South Sumatra Province (Dyahningtyas et al., 2019). Simply as explained earlier, the fiscal illusion can be explained as a form of imbalance between increasing balancing funds and PAD on regional expenditure, in other words regional expenditure will be dominated by funds originating from the center. Detection of fiscal illusions can be done in various ways, three of them with Revenue Enhancement, Expenditure Manipulation, and Debt Utilization. Revenue enhancement assumes that regional income has a positive correlation with regional expenditure,approach expenditure manipulation will look at the role of revenue sources in PAD budgeting, and debt utilization can describe the portion of debt utilization used to finance regional expenditure (Yoduke, 2018; Dyahningtyas et al., 2019). Research on fiscal illusions has been carried out by various researchers both nationally and internationally. The phenomenon of low levels of regional independence in regencies / cities in South Sumatra Province indicates a deviant behavior towards transfers given by the central government to regional governments. This can affect the efforts of local governments to increase PAD. Nevertheless, these indications require empirical testing and verification. So, this research was conducted with the aim of detecting the existence of fiscal illusions and knowing the factors that influence fiscal illusions that occurred in regencies / cities of South Sumatra Province in the period 2012-2018.

\section{Literature Review}

\subsection{Fiscal Illusion Theory}

Amilcare Puviani, an economist from Italy, was the first person to introduce fiscal illusion theory. Amilcare Puviani explained that fiscal illusion occurs when an authorized decision maker in an institution makes a financial illusion that causes changes in financial behavior (Puviani, 1976). Adi \& Ekaristi (2009) provides a definition of fiscal illusion when local governments 
manipulate financial statements that can direct a person or users of financial statements to certain views or behaviors. Detecting fiscal illusions can be done by analyzing both the revenue side and the expenditure side. If there is an asymmetric response related to revenue or expenditure, it can indicate a fiscal illusion. Some concept approaches to detect fiscal illusions can be done through revenue enhancement, expenditure manipulation, debt utilization. Detect fiscal illusion with revenue enhancement approach has the assumption that each income will be positively correlated to regional expenditure, because regional revenue and expenditure are one and the same function unit (Dyahningtyas et al., 2019). Expenditure manipulation approach detecting fiscal illusions by looking at the role of the regional revenue share that has a positive relationship with increasing PAD budgeting in the following year. Detection fiscal illusion through the debt utilization approach, according to Barro (1974) in Yoduke (2018) states that a simple measurement of fiscal illusion can be done by comparing the use of debt with PAD to regional expenditure. The dominant use of debt compared to the contribution of PAD in regional expenditure shows the illusion of debt.

\subsection{Previous Research}

Various researchers up to 2019 have tested the phenomenon of fiscal illusion in the management of local government finances in diverse countries and regions, such as research conducted by Logan (1986); Turnbull (1992); Gemmell et al. (1999); B. E. Dollery \& Worthington (1999); Kuncoro (2007); Adi \& Ekaristi (2009); Bhakti (2013); Dude et al. (2014); Rusydi (2015); Armawaddin (2015); Salawali et al. (2016); Pratami \& Dwirandra (2017); Susilawati et al. (2018); Dwirandra et al. (2017); Nugroho (2017); Nurhayati (2017); Tasri (2018); Meilya \& Herwanti (2018); Hapsoro \& Yoduke (2019); Dyahningtyas et al. (2019). Based on research conducted by Pratami \& Dwirandra (2017) entitled "The Effect of PAD, Balance Funds, LPDS, and PDRB on Regional Expenditures and Fiscal Illusion Detection”. Researchers conducted research aimed at examining the influence of local revenue sources, PDRB on regional expenditure and detecting fiscal illusions in the financing of regencies / cities government expenditure in Bali Province. The results showed that tax and DAU had a significant positive effect on regional expenditure, then LPDS and PDRB had no significant positive effect on regional expenditure, HCT, DAK, and DBH had a significant negative effect on regional expenditure, and there was no fiscal illusion. Furthermore, research conducted by Hapsoro \& Yoduke (2019) entitled "Detection of Fiscal Illusions and Their Effects on Economic Growth". The purpose of this study is to detect fiscal illusions in the form of Flypaper Effect and illusion of debt in local government expenditure and their effect on regional economic growth in Sulawesi. This research shows the results that there is a phenomenon of fiscal illusion in the form of Flypaper Effect and debt fiscal illusion in local government expenditure and fiscal illusion has a significant positive effect on economic growth. Dyahningtyas et al. (2019) conducted a study entitled "Regional Financial Performance and Detection of Fiscal Illusions in Regencies / Cities Governments of Special Region of Yogyakarta in 2010-2016”. This study aims to determine the financial performance of regencies / cities in the province of DIY and detect the phenomenon of fiscal illusion in regencies / cities in the province of DIY. The results of this study indicate that the average regional independence ratio is $30.38 \%$, consultative relationship pattern. The degree of fiscal decentralization of $17.35 \%$ means that the ability of the government in managing regional finances is still lacking and researchers found that in regencies / cities in the Province of DIY there has been a fiscal illusion on financial management.

\subsection{Framework}

Fiscal Illusion Detection conducted with theapproachrevenue enhancementassumes that regional revenue will have a positive relationship to regional expenditure (Yoduke, 2018; Dyahningtyas et al., 2019). The independent variable in the revenue enhancement approach in this study is the component of regional revenue, namely gross regional domestic product, regional tax, regional retribution, DAU, and $\mathrm{DBH}$ on regional expenditure. This is because basically the government can realize expenditure when it has the ability and source of revenue to finance these expenditures. The concept of expenditure manipulation assumes that if there is a negative correlation between PAD budgeting and the ratio of national income, the relative perceptions of the central government and regional governments, as well as the relative importance of DAU on regional government expenditure (Adi \& Ekaristi, 2009). Detection of fiscal illusions by measuring debt utilization assumes that regional expenditure funding is more dominated by PAD than regional debt (Yoduke, 2018; Dang et al., 2020). Based on the test of the 3 concepts of fiscal illusion detection above, if the three concepts of test results show that there is no fiscal illusion, then the conclusion is that the financial management of regional government does not occur. However, if of the three concepts there are one, two or even three concepts detecting fiscal illusions, it can be concluded that fiscal illusions occur.

\section{Research Methods}

Type of research is quantitative research. The sample used in this study was in 15 regencies / cities in South Sumatra Province during 2012 to 2018. This study will detect fiscal illusions through 3 approaches, namely detection of fiscal illusions through revenue enhancement approach, expenditure manipulation approach, and debt utilization approach. The analytical method used is panel data regression using secondary data in the form of financial and non-financial data. Before conducting a regression analysis on each panel data regression model, on each model several classical assumption tests and a model feasibility test will be conducted. The classic assumption test conducted in this study is the multicollinearity and heteroscedasticity, while the 
feasibility test for the model in this study is intended to determine the best estimation of the model. Tests to be performed are the chow test, thetest hausman test, and the lagrange multiplier test. After the equation model is free from the classical assumption problem and the best estimation model is determined, it will proceed with a panel data regression analysis on each research model. The following description of the model and design of the study is explained in the section below:

\subsection{Fiscal Illusion Detection Through Revenue Enhancement Approach}

This study uses a research model that is used by Dude et al. (2014); Dyahningtyas et al. (2019); Nurhayati (2017) as for the model :

\section{Model I :}

$$
B D=\alpha_{0}+\alpha_{1} P D R B_{t, i}+\alpha_{2} P_{j} j_{t, i}+\alpha_{3} \operatorname{Ret}_{t, i}+\alpha_{4} D A U_{t, i}+\alpha_{5} D B H_{t, i}+e .
$$

Description :

$\begin{array}{llll}B D & =\text { Regional expenditure } & \text { Ret } & =\text { Regional Retribution } \\ \alpha & =\text { constant } & D A U & =\text { General Allocation Fund } \\ P D R B & =\text { Gross Regional Domestic Product (PDRB) } & D B H & =\text { Special Allocation Fund } \\ P a j & =\text { Regional Tax } & e & =\text { std. } \text { Error }\end{array}$

Correlation of income and expenditure variables must be positive. In this study, the hypothesis (Ha) is accepted when there is a negative correlation on the independent and dependent variables. if the results show a fiscal illusion through this approach, then it will proceed with answering the second problem formulation through Eq. (2), where $B D$ 'is proxied by BD regression results of Eq. (1), while Eq. (2) is formed as follows:

$$
B D^{\prime}=\beta_{0}+\beta_{1} P D R B_{t, i}+\beta_{2} P a j_{t, i}+\beta_{3} \operatorname{Ret}_{t, i}+\beta_{4} D A U_{t, i}+\beta_{5} D B H_{t, i}+e .
$$

However if a fiscal illusion is not detected through the approach Revenue Enhancement, then testing to answer the formulation of the second problem need not be continued.

\subsection{Fiscal Illusion Detection Through Manipulation Expenditure Approach}

Dollery \& Worthington (1995); Adi \& Ekaristi (2009) measure expenditure manipulation through:

\section{Model II :}

$$
A P A D=\delta_{0}+\delta_{1} P N_{t-1, i}+\delta_{2} P R_{t-1, i}+\delta_{3} K R_{t-1, i}+\delta_{4} U_{t-1, i}+e
$$

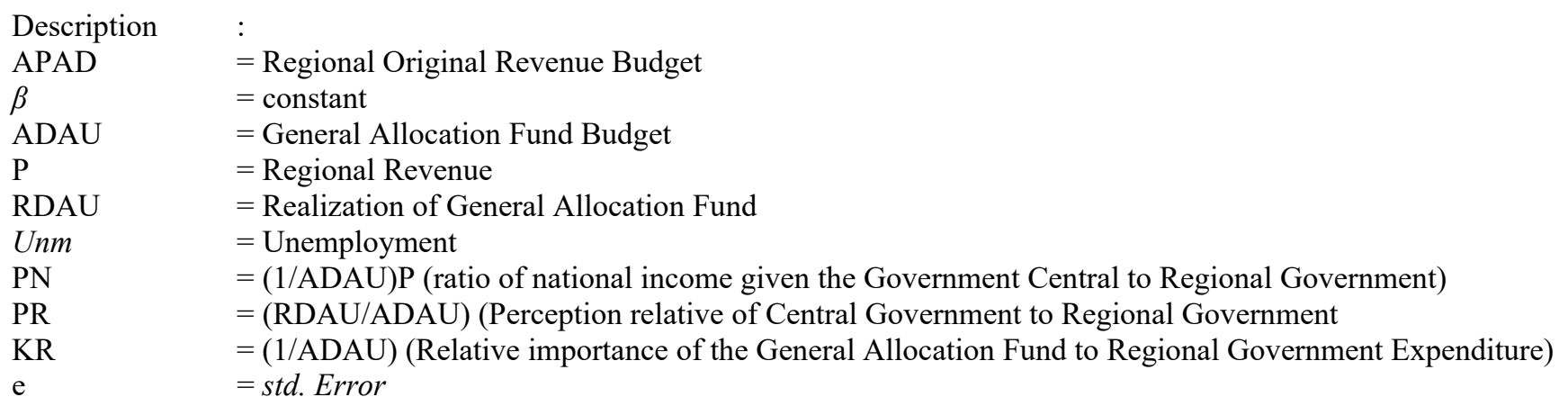

The ratio variable of national income given by the central government to regional governments illustrates the contribution of DAU to total regional revenue. The relative perception variable of the central government towards regional governments explains the central government's perception of the effectiveness of the use of DAU given to Regional governments. The relative importance variable of DAU on regional government expenditure illustrates the level of dependence of regional governments on DAU to finance regional expenditure. In this variable, the smaller the ratio shows the higher the level of dependence (Adi \& Ekaristi, 2009; Utari, 2015). The unemployment rate variable is an institutional constraint (Hammes \& Wills, 1987). B. E. 
Dollery \& Worthington (1999); Adi \& Ekaristi, (2009); Utari (2015) explains that if $A P A D$ is negatively correlated with significant values with $P N, P R$, and $K R$, a fiscal illusion is indicated. In addition, Logan (1986); Hammes \& Wills (1987); B. Dollery \& Worthington (1995); Adi \& Ekaristi (2009); Utari (2015) states that if Unm is positively related to significant value of $A P A D$, then it shows a fiscal illusion, this is because unemployment is one of the variations in regional expenditure and high unemployment can have an impact on the reduced ability of people to pay taxes and contribute on increasing PAD. Thus, the hypothesis (Ha) is accepted or a fiscal illusion occurs if $(P N, P R$, and $K R$ have a negative effect on $A P A D$, and if there is a positive correlation between $A P A D$ andvariables $U n m$ ), if the detection results show a fiscal illusion through the expenditure manipulation approach, then it will proceed with answering the fourth problem formulation by doing regression in Eq. (4) $A P A D$ ' is a fiscal illusion resulting from regression of Eq. (3), Eq. (4) can be seen below:

$$
A P A D^{\prime}=£_{0}+£_{1} P N_{t-1, i}+£_{2} P R_{t-1, i}+£_{3} K R_{t-1, i}+£_{4} U_{t-1, i}+e .
$$

If no fiscal illusion is detected through the expenditure manipulation approach with Eq. (3), then testing in Eq. (4) is not necessary to answer the fourth problem formulation.

\subsection{Fiscal Illusion detection through Debt Utilization Approach}

Barro (1974) in Yoduke (2018) states that the measurement of fiscal illusion with this approach, it can simply be done by comparing the utilization of debt with PAD to shopping areas. Measurements can be made using the following model Yoduke (2018):

\section{Model III :}

$$
B D=€_{0}+€_{1} P A D_{t, i}+€_{2} D e b t_{t, i}+e .
$$

$\mathrm{BD} \quad=$ Regional Expenditures

e $\quad=$ Constant

$\mathrm{PAD}=$ Regional Original Revenue

Debt $=$ Regional Debt

$\mathrm{E} \quad=$ std. Error

The dominant use of debt compared to the contribution of PAD in regional expenditure indicates the occurrence of debt illusions. But on the contrary, if the use of PAD is more dominant towards regional expenditure, it can be said that there is no debt illusion. The hypothesis (Ha) is accepted if PAD participation is lower than debt participation in regional expenditure. When the results show that there has been a fiscal illusion, the next process is to answer the sixth problem formulation in this study using Eq. (6) below :

$$
B D^{\prime}=\partial_{0}+\partial_{1} P A D_{t, i}+\partial_{2} D e b t_{t, i}+e
$$

However, if the results of regression Eq. (5) show there is no fiscal illusion, then the regression test using Eq. (6) to fight the formulation of the sixth problem need not be continued.

\section{Results and Discussion}

\subsection{Research result}

This research in answering the problem formulation begins by detecting fiscal illusion through 3 models, each of which is detection of fiscal illusion through theapproach revenue enhancement with Eq. (1) model 1, approach expenditure manipulation with Eq. (3) model 2, and debt utilization with Eq. (5) of model 3. Type the regression results in each model to detect a fiscal illusion, then the data will be estimated again to determine the probability. The probability value will be used as the dependent variable which is explained by several explanatory variables in each model. The next regression equation that is formed in each model is, Eq. (2) in model 1, Eq. (4) in model 2, and Eq. (6) in model 3.

Detection of fiscal illusions through revenue enhancement approach aims to see the existence of fiscal illusions that occur in regencies / cities in South Sumatra Province associated with an increase in the amount of regional income that can affect the amount of regional expenditure. Detection of fiscal illusions through expenditure manipulation approach is intended to detect the presence of fiscal illusions that occur in the utilization and effectiveness of central government transfer assistance funds, specifically the DAU to increase PAD which is used as an indicator of regional independence. The third approach, namely the 
detection of fiscal illusions through the debt utilization approach with the aim of detecting the existence of fiscal illusions that occur in regencies / cities in South Sumatra Province related to the use of regional debt in financing regional expenditure. The following test results have been described and explained in the sections below.

\subsubsection{Fiscal Illusion detection through Revenue Enhancement}

Descriptive statistics of Eq. (1) model 1 indicates that the variable BD namely, shopping area minimum value 514.6 Million owned by Empat Lawang in 2012 and the maximum value is owned by Regency MUBA (Musi Banyuasin in 2014 amounted to 3.52 Trillion. The lowest GRDP variable was owned by the City of Pagaralam in 2012, which was valued at 1.64 billion and Palembang City with the highest GRDP in 2012 amounting to 98.7 billion. Regional tax variable, the minimum value owned by South Ogan Komering Ulu Regency (OKUS) in 2012 was 3.65 billion and the maximum value was owned by Palembang City with a figure of 721 billion in 2018. The next variable was that regional retribution had the lowest value of 464.9 Million owned by the Empat Lawang Regency in 2018 and the highest number was 118 billion by the city of Palembang in 2013 . The DAU variable, the lowest value was obtained by the Musi Banyuasin regency in 2015, amounting to 131 billion and the highest value was owned by the city of Palembang with a number of 1.29 Trillion. South OKU Regency DBH variable in 2018 was the regency that received the lowest $\mathrm{DBH}$ of 35.5 billion, while the highest figure was obtained by Musi Banyuasin Regency in 2014, amounting to 2.42 trillion. The following results of descriptive statistics of Eq. (1) model 1 are presented in Table 1.

Table 1

Results of Descriptive Statistics Eq. (1) Model 1

\begin{tabular}{ccccccc}
\hline & BD & PDRB & PAJ & RET & DAU & DBH \\
\hline Mean & $1,35 \mathrm{~T}$ & $16,6 \mathrm{M}$ & $60,1 \mathrm{M}$ & $12,4 \mathrm{M}$ & $595 \mathrm{M}$ & $37,9 \mathrm{M}$ \\
Maximum & $3.52 \mathrm{~T}$ & $98,7 \mathrm{M}$ & $721 \mathrm{M}$ & $118,3 \mathrm{M}$ & $1,29 \mathrm{~T}$ & $2,42 \mathrm{~T}$ \\
Minimum & $514,6 \mathrm{Juta}$ & $1,64 \mathrm{M}$ & $3,65 \mathrm{M}$ & $464,9 \mathrm{Juta}$ & $131 \mathrm{M}$ & $35,6 \mathrm{M}$ \\
Std. Dev. & $677 \mathrm{M}$ & $20,9 \mathrm{M}$ & $127 \mathrm{M}$ & $21,7 \mathrm{M}$ & $24,9 \mathrm{M}$ & $45,7 \mathrm{M}$ \\
Observations & 105 & 105 & 105 & 105 & 105 & 105 \\
Cross sections & 15 & 15 & 15 & & & 15 \\
\hline
\end{tabular}

The results of the classic assumption test show that the regression model I is free fromproblems multicollinearity and heteroscedasticity. In addition, the results of the model feasibility test show that the best estimation model that can be used in model 1 is the fixed effect model. Furthermore, the results of statistical tests can be seen in Table 2. below:

Table 2

Equation Statistical Test Results (1) Model 1 Dependent Variabel: LOG(BD?)

\begin{tabular}{|c|c|c|c|c|c|}
\hline Variabel & Coefficient & Std. Error & t-Statistic & Prob. & Description \\
\hline $\mathrm{C}$ & 11.65002 & 4.905428 & 2.374925 & 0.0198 & \\
\hline LOG(PDRB?) & 0.145652 & 0.198168 & 0.734992 & 0.4644 & There is no fiscal illusion \\
\hline LOG(PAJ?) & 0.100851 & 0.040614 & 2.483171 & 0.0150 & There is no fiscal illusion \\
\hline LOG(RET?) & 0.027935 & 0.029490 & 0.947275 & 0.3462 & There is no fiscal illusion \\
\hline LOG(DAU?) & 0.341668 & 0.079899 & 4.276272 & 0.0000 & There is no fiscal illusion \\
\hline LOG(DBH?) & 0.020718 & 0.048393 & 0.428130 & 0.6696 & There is no fiscal illusion \\
\hline R-squared & \multicolumn{2}{|r|}{0.930179} & \multicolumn{2}{|c|}{ Durbin-Watson stat } & 1.615002 \\
\hline Adjusted R-squared & \multicolumn{2}{|r|}{0.914572} & & & \\
\hline F-statistic & \multicolumn{2}{|r|}{59.60000} & & & \\
\hline Prob(F-statistic) & \multicolumn{2}{|r|}{0.000000} & & & \\
\hline
\end{tabular}

The statistical test results in Table 1 show that the F-statistic value in Eq. (1) model 1 is 59.60 which means it is greater than the F-table, which is 2.19 and avalue probability smaller than 0.05 . The PDRB variable, local tax, regional retribution, DAU, and DBH together have a significant positive effect on regional expenditure at a 95\% confidence level.Numbers Adjusted R-Square is 0.914 which shows that as much as $91.4 \%$ of regional expenditure variables can be explained by the variable PDRB, local taxes, regional levies, DAU and DBH. While $8.6 \%$ is explained by other variables not explained in this model. Based on the test results it is known that all independent variables, namely GRDP, local taxes, regional levies, DAU and DBH have positive coefficient signs on regional expenditure. So it can be concluded that Ho was rejected, in regencies / cities in South Sumatra Province there was no fiscal illusion detected through theapproach revenue enhancement. This study is in line with Pratami \& Dwirandra (2017) which in the study found that in the regencies / cities in Bali Province there was no fiscal illusion. In the previous section it has been explained if the test results in model 1 with Eq. (1) do not detect fiscal illusions, then regression testing on Eq. (2) of model 1 to answer the second problem formulation is not necessary. Thus, testing model 1 to detect fiscal illusion is sufficient in this section and no further testing is needed to Eq. (2) model 1 to answer the problem formulation and hypothesis 2 . 


\subsubsection{Fiscal Illusion Detection with Approach Expenditure Manipulation}

Descriptive statistics generated by Eq. (3) model 2 shows the number of units of analysis (N) of 105 units. The following descriptive statistical results in this study are presented in Table 3. below.

Table 3

Descriptive Statistics Results Eq. (3) Model 2

\begin{tabular}{cccccc}
\hline & APAD & PN & PR & KR & Unm \\
\hline Mean & $161 \mathrm{M}$ & 2.611032 & 0.992592 & 0.000000000002100 & 5.051881 \\
Maximum & $1.10 \mathrm{~T}$ & 15.52583 & 1.029835 & 0.0000000000007600 & 12.31000 \\
Minimum & $13.2 \mathrm{M}$ & 1.267843 & 0.309780 & 0.000000000000800 & 0.920000 \\
Std. Dev. & $214 \mathrm{M}$ & 1.827592 & 0.068009 & 0.0000000000000956 & 105 \\
Observations & 105 & 105 & 105 & 15 & 105 \\
Cross sections & 15 & 15 & 15 & & 15 \\
\hline
\end{tabular}

Based on the test results in Table 3. it is known that the APAD variable, namely, the PAD budget has a minimum value of 13.2 billion owned by South OKU Regency in 2012 and the maximum owned by the City of Palembang in in 2018 amounted to 1.10 Trillion. The variable ratio of national income provided by the central government to local governments with the lowest value owned by Musi Rawas Regency in 2018, which is 1.27 and the highest ratio of 15.53 in 2016 owned by Musi Banyuasin Regency. The relative perception variable of the central government towards local governments which shows the minimum value owned by South Ogan Komering Ulu Regency (OKUS) in 2017 is 0.31 and the maximum value is owned by Musi Rawas Regency, which is 1.03 in 2018. The next variable, namely the relative importance of DAU on regional expenditure, the lowest value was 0.0000000000000800 from Palembang City in 2017. While the highest number was 0.000000000007600 owned by Musi Banyuasin Regency in 2016. The lowest unemployment variable was obtained by Musi Rawas regency in 2014, which is $0.92 \%$ and the highest value is owned by Lubuk Linggau City with a figure of $12.31 \%$. The classical assumption test results of Eq. (3) model 2 in this study show that Eq. (3) model 2 is free from the classic assumptions of multicollinearity and heteroscedasticity. And the best estimation model in this equation is the fixed effect model. Statistical test results can be seen in Table 4. below:

\section{Table 4}

Results of Statistical Analysis of Eq. (3) Model 2

\begin{tabular}{|c|c|c|c|c|c|}
\hline \multicolumn{6}{|c|}{ Dependent Variabel: LOG(APAD?) } \\
\hline $\begin{array}{r}\text { Variabel } \\
\end{array}$ & Coefficient & Std. Error & t-Statistic & Prob. & Description \\
\hline $\mathrm{C}$ & 26.50266 & 0.587241 & 45.13082 & 0.0000 & \\
\hline PN? & 0.681512 & 0.070955 & 9.604845 & 0.0000 & There is no fiscal illusion \\
\hline PR? & -0.823403 & 0.571517 & -1.440733 & 0.1533 & There is no fiscal illusion \\
\hline $\mathrm{KR} ?$ & $-1.09 \mathrm{~T}$ & $91.2 \mathrm{M}$ & -11.95713 & 0.0000 & There is fiscal illusion \\
\hline Unm? & 0.024968 & 0.026344 & 0.947771 & 0.3459 & There is no fiscal illusion \\
\hline R-squared & 0.876545 & & Natson stat & & 1.994618 \\
\hline Adjusted R-squared & 0.850705 & & & & \\
\hline F-statistic & 33.92274 & & & & \\
\hline Prob(F-statistic) & 0.000000 & & & & \\
\hline
\end{tabular}

The results of statistical tests show that the value of the regression Eq. (3) of Model 2 F-statistics is 33.92 which means it is greater than the F-table, which is 2.31 and the value of propability which is smaller than 0.05 . The variable ratio of national income given by the central government to regional governments, the relative perceptions of the central government towards regional governments, the relative importance of DAU to regional expenditure, and the unemployment rate together have a significant positive effect on the PAD budget at a $95 \%$ confidence level. Thefigure adjusted $R$-Square is 0.850 which shows that $85 \%$ of the national income ratio variable given by the central government to regional governments, the relative perception of the central government towards regional governments, the relative importance of DAU to regional expenditure, and the unemployment rate. Whereas $15 \%$ is explained by other variables not explained in this model. This approach assumes that fiscal illusion is detected if there are one or more Independent variables $(P N, P R$, and $K R)$ that are negatively correlated and have a significant value to the budget variable PAD (APAD) and / or unemployment variable (Unm) positively correlated with the value significant to APAD (B. Dollery \& Worthington, 1995). Based on the test results above, it is known that among the independent variables, only the relative importance variable of DAU towards regional expenditure has a negative coefficient sign and a significant value to the PAD budget. This means that in regencies / cities in South Sumatra Province there is a fiscal illusion detected through theapproach expenditure manipulation. The results of this study are in line with research conducted by Adi \& Ekaristi (2009); B. E. Dollery \& Worthington (1999) who in his research found that there is a fiscal illusion in local government. Based on the explanation in Chapter 3 earlier, if the results of the equation 2 test (model 2) detect a fiscal illusion, it is necessary to carry out further regression testing using Eq. (4) model 2 to answer the problem formulation and the fourth 
hypothesis in this study. The next regression test will use the dependent variable in the form of a probability of fiscal illusion detected through Eq. (3) of model 2. Furthermore, the dependent variable will be regressed with explanatory variables in the previous model. The following is a continued regression in model 2 to determine the explanatory factors affecting the detected fiscal illusion.

\subsubsection{Factors in the Expenditure Manipulation Approach Explain the Fiscal Illusion Detected}

Eq. (4) of model 2 has descriptive statistics which can be seen in Table 5 :

Table 5

Descriptive Statistics Results Eq. (4) Model 2

\begin{tabular}{|c|c|c|c|c|c|}
\hline & APAD' & $\mathbf{P N}$ & PR & KR & Unm \\
\hline Mean & 25.32101 & 2.611032 & 0.992592 & $2.10 \mathrm{E}-12$ & 5.051881 \\
\hline Maximum & 28.33398 & 15.52583 & 1.029835 & 7.60E-12 & 12.31000 \\
\hline Minimum & 22.59566 & 1.267843 & 0.309780 & $8.00 \mathrm{E}-13$ & 0.920000 \\
\hline Std. Dev. & 1.125341 & 1.827592 & 0.068009 & $9.56 \mathrm{E}-13$ & 2.313907 \\
\hline Observations & 105 & 105 & 105 & 105 & 105 \\
\hline Cross sections & 15 & 15 & 15 & 15 & 15 \\
\hline
\end{tabular}

The dependent variable in this equation is the value of fiscal illusion probability which is the result of estimation of data in model 2. This variable has a minimum value of 22.59 owned by Pagaralam City in 2012 . While the maximum value of fiscal illusion is owned by Musi Banyuasin Regency in 2015, amounting to 28.33. The value of fiscal illusion shows the score of fiscal illusion that occurred in the regencies / cities. Descriptive statistics of the variable ratio of national income given by the central government to regional governments, the relative perceptions of the central government towards regional governments, the relative importance of DAU to regional expenditure, and unemployment have been explained in Eq. (3) of model 2.

Based on the results of the classical assumption test and the feasibility test of equation model (4) model 2 it is known that this equation model is free fromproblems multicollinearity and heteroscedasticity with the best model estimation using the Random Effect Model. The following are the results of the statistical test for Eq. (4) of model 2.

\section{Table 6}

Results of Statistical Analysis of Equations (4) Model 2

\begin{tabular}{|c|c|c|c|c|}
\hline \multicolumn{5}{|l|}{ Dependent Variabel: APAD’? } \\
\hline Variabel & Coefficient & Std. Error & t-Statistic & Prob. \\
\hline $\mathrm{C}$ & 26.51446 & 0.047429 & 559.0325 & 0.0000 \\
\hline PN? & 0.681483 & 0.002198 & 310.0518 & 0.0000 \\
\hline PR? & -0.816111 & 0.047687 & -17.11398 & 0.0000 \\
\hline $\mathrm{KR}$ ? & $-1.10 \mathrm{E}+12$ & $4.14 \mathrm{E}+09$ & -265.2376 & 0.0000 \\
\hline Unm? & 0.028509 & 0.001453 & 19.62492 & 0.0000 \\
\hline R-squared & 0.999104 & Durbin- & & 2.221092 \\
\hline Adjusted R-squared & 0.999068 & & & \\
\hline F-statistic & 27876.53 & & & \\
\hline Prob(F-statistic) & 0.000000 & & & \\
\hline
\end{tabular}

The results of statistical tests show that all of the variables together have a significant positive effect on fiscal illusion. This is indicated by the F-statistic value of 27876.53 which is greater than the F-table, which is 2.31 and avalue propability smaller than 0.05 . Thefigure adjusted R-Square is 0.99 , which shows that $99 \%$ of the national income ratio variable is given by the central government to regional governments, the relative perception of the central government to regional governments, the relative importance of DAU to regional expenditure, and unemployment. Whereas $1 \%$ is explained by other variables not explained in this model. Partially, all independent variables $(P N, P R$, and $K R)$ influence the fiscal illusion with the t-statistic value of each variable greater than the t-table, which is 1.98 and thevalue probability is smaller than 0.05 .

\subsubsection{Fiscal Illusion Detection with Debt Utilization Approach}

The next approach model for detecting fiscal science is the debt utilization approach. Descriptive statistics for Eq. (5) of model 3 are shown in Table 7. Variable BD in Eq. (5) model 3 is regencies / cities regional expenditure in South Sumatra Province which is also used in Eq. (1) of model 1 before with the same descriptive statistical value. The PAD variable has a minimum value owned by the South OKU Regency of 18.9 billion and a maximum value of 1.09 Trillion owned by the City of Palembang. The variable debt with the lowest number is 0.0 in South OKU Regency in 2013 and the highest number is 354 billion owned by Muaraenim Regency in 2016. The results of testing the classical assumptions of multicollinearity and heteroscedasticity, 
knowing the concept of this equation is free from the constraints of classical assumptions. The model feasibility test results show that the best estimate is to use the fixed effect model. The following Table 8. presents the results of the statistical test Eq. (5) model 3.

Table 7

Results of Descriptive Statistics of Eq. (5) of Model 3

\begin{tabular}{cccc}
\hline & BD & PAD & Debt \\
\hline Mean & $1,35 \mathrm{~T}$ & $136 \mathrm{M}$ & \\
Maximum & $3.52 \mathrm{~T}$ & $1,09 \mathrm{~T}$ & \\
Minimum & $514,6 \mathrm{Juta}$ & $18,9 \mathrm{M}$ & \\
Std. Dev. & $677 \mathrm{M}$ & $185 \mathrm{M}$ & 105 \\
Observations & 105 & $8,27 \mathrm{M}$ & 105 \\
Cross sections & 15 & 15 & 15 \\
\hline
\end{tabular}

\section{Table 8}

Results of Statistical Analysis of Eq. (5) Model 3

Dependent Variabel: BD?

\begin{tabular}{|c|c|c|c|c|c|}
\hline Variabel & Coefficient & Std. Error & t-Statistic & Prob. & Description \\
\hline $\mathrm{C}$ & $1.10 \mathrm{~T}$ & $5.21 \mathrm{M}$ & 21.09571 & 0.0000 & \multirow{3}{*}{ There is no fiscal illusion } \\
\hline PAD? & 1.887985 & 0.354056 & 5.332447 & 0.0000 & \\
\hline Debt? & -0.014797 & 0.317950 & -0.046538 & 0.9630 & \\
\hline $\bar{R}$-squared & 0.920995 & Durbin-Watson stat & & & 1.945504 \\
\hline Adjusted R-squared & 0.906465 & & & & \\
\hline F-statistic & 63.38737 & & & & \\
\hline $\operatorname{Prob}(\mathrm{F}$-statistic) & 0.000000 & & & & \\
\hline
\end{tabular}

Based on the above test results, it is known that the F-statistic value in Eq. (5) of model 3 is 63.38 which means it is greater than the F-table, which is 2.69 and avalue probability smaller than 0.05. The PAD andvariables Debt together have a significant positive effect on regional expenditure at a 95\% confidence level.Numbers Adjusted R-Square is 0.92 which shows that $92 \%$ of regional expenditure variables can be explained by the PAD andvariables Debt. While $8 \%$ is explained by other variables not explained in this model. Partially, the t-statistic value of PAD variable is $1.88<\mathrm{t}$-table that is 1.98 , but the probability is $0.00>$ 0.05 , meaning that the PAD variable has a significant positive effect on regional expenditure (BD). Furthermore, the t-statistic value ofvariable Debt is 0.01 (with a negative sign) $<\mathrm{t}$-table that is 1.98 and the probability of $0.96>0.05$, meaning that thevariable Debt does not have a significant positive effect on regional expenditure (BD). This means that the regencies / cities government in South Sumatra Province does not focus on the use of debt in financing regional expenditures.

\subsection{Discussion}

The results of the research described in the previous point explain that of the 3 models (Model 1, Model 2, Model 3) tested in this study to detect fiscal illusions, there is only 1 model that detects fiscal illusions that occur in regencies / cities in the Province South Sumatra for the period 2012-2018.

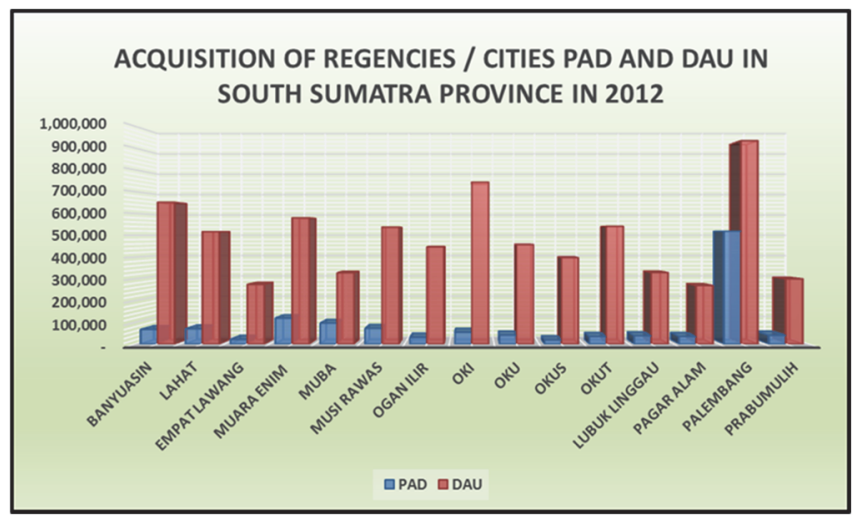

Fig. 3. Acquisition of Regencies / Cities PAD and DAU in South Sumatra Province in 2012 Source: data processed, 2020

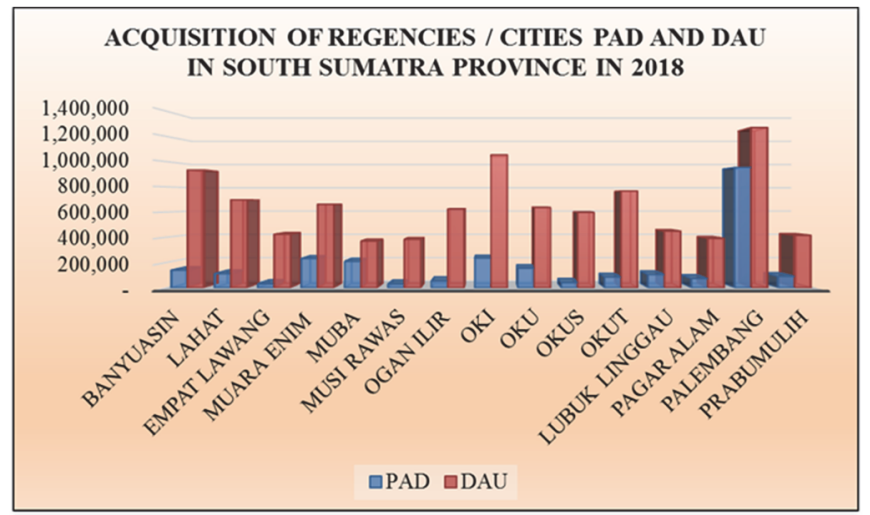

Fig. 4. Acquisition of Regencies / Cities PAD and DAU in South Sumatra Province in 2018

The model is model 2 which detects fiscal illusions through theapproach expenditure manipulation. Thus, further regressions in this study are only carried out on models that detect the existence of these fiscal illusions. The results of the further regression 
are done by Eq. (4) model 2 and the test results show that the national income ratio variable given by the central government to regional governments has a significant positive effect on the detected fiscal illusion. This variable shows how much the DAU contributed to the regencies / cities regional revenue in the South Sumatra Province. The greater DAU contribution to regional revenue, according to Nanga (2005) in Adi \& Ekaristi (2009) can trigger fiscal illusion. Local governments are motivated to continue to increase expenditure but are not accompanied by a significant increase in PAD. This is proven and clarified again by comparative data on the acquisition of PAD and DAU in 2012 to 2018. Fig. 3 is a comparison chart of the acquisition of PAD and DAU in the regencies / cities in South Sumatra Province in 2012. Figure 3. shows that regencies / cities in South Sumatra Province in the period 2012 to 2018 had a relatively higher amount of DAU compared to PAD. In addition, Fig. 4. The following also shows a similar comparison of the acquisition of regencies / cities PAD and DAU in South Sumatra Province in 2018. The large amount of DAU received by the regencies / cities government in South Sumatra Province should motivate the government to utilize its use in regional expenditure which can have a significant impact on increasing PAD acquisition. Thus, the regional government will gradually reduce the level of dependence on the DAU and give a signal to the central government that the region has the potential to be independent in financing regional expenditure through PAD (Dwirandra et al., 2017). However, until 2018 the acquisition of regencies / cities PAD in South Sumatra Province is still far from the total PAD acquisition. Subsequent test results stated that the relative perception variable of the central government towards regional governments in realizing DAU had a negative effect on fiscal illusion. Incorrect perceptions from the central government related to the effectiveness of the use of DAU by the regencies / cities government in the South Sumatra Province can lead to opportunities for fiscal illusion. The central government needs to ensure that the DAU provided is on purpose and on the intended target. The higher level of effectiveness of DAU utilization that is used appropriately will have an impact on increasing the amount of PAD revenue in the following year, thereby reducing the potential for fiscal illusion. The initial purpose of the central government to provide DAU is to help local governments finance expenditures that have not been fully able to be financed through PAD revenues, with the hope that the DAU will be utilized to explore regional potentials that can influence the increase of PAD in the following year. Therefore, if the amount of DAU given annually increases, but it is not balanced with an increase in PAD, this shows the unproductive allocation of the central government funding sources provided and needs to be a point of more concern for the central government to be re-evaluated (Pratami \& Dwirandra, 2017). The next result of the statistical analysis of this study is that the relative importance of local government variables on the DAU used for regional expenditure negatively influences the fiscal illusion. This variable illustrates the dependence of regional governments on central government assistance in the form of DAU. The smaller relative importance ratio means that it is reversed to the level of dependency of regional governments. That is, the ratio of relative importance decreases, so it shows the level of dependency of local governments is increasing. So, when the dependency gets higher the score fiscal illusion will increase. This can be seen through graphs that illustrate the trend of relative interest ratios and the following fiscal illusions:

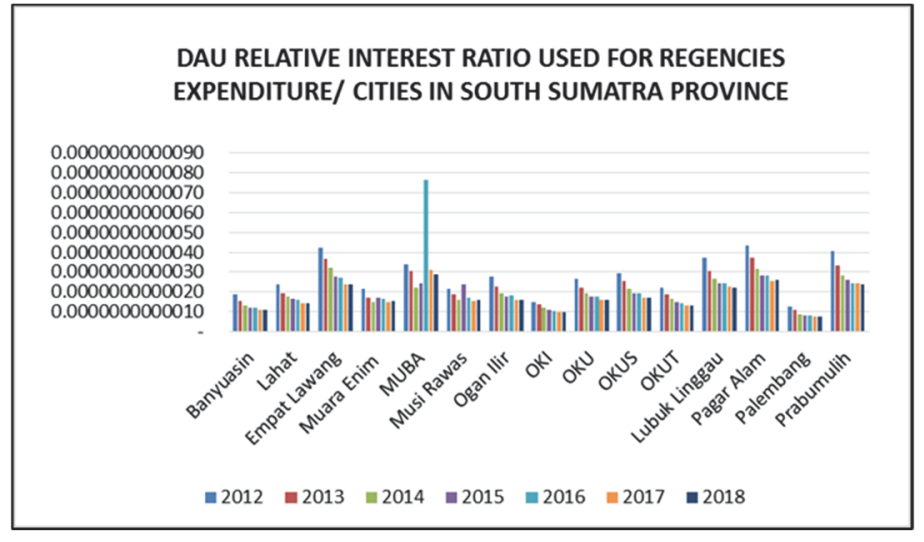

Fig. 5. DAU Relative Interest Ratio Used for Regencies Expenditure/ Cities in South Sumatra Province

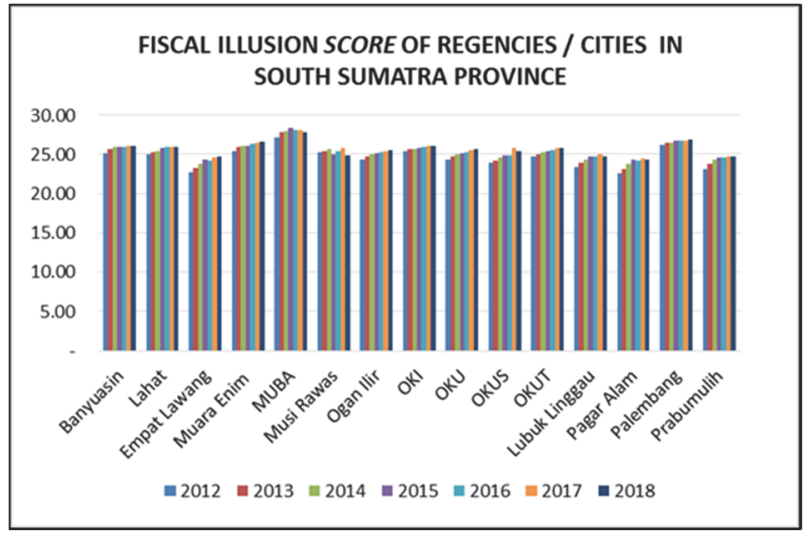

Fig. 6. Fiscal Illusion Score of Regencies / Cities in South Sumatra Province

\section{Source: data processed, 2020}

Fig. 5. shows that the decreasing trend of graphs means that the level of dependence of regional governments on DAU to increase regional expenditure is increasing. High level of dependency for regencies / cities in South Sumatra Province will give rise to the potential of local governments to carry out fiscal illusions. The graph of fiscal illusion is shown in Fig. 6 . The effect that can arise from the increasingly dependent local governments on the central government can lead to fiscal illusion in exploring the potential of existing regions. This means that in each period to period the local government will strive to obtain a high DAU rather than seriously trying to increase PAD. Because, when the PAD has increased from year to year, the value of the DAU given will decrease further and the central government will view the regional government as having independently financed 
expenditure through PAD (Utari, 2015). This research also proves that the unemployment rate has a positive effect on fiscal illusions. This means that when there is an increase in the unemployment rate it can lead to potential fiscal illusions. Utari (2015) states that unemployment often causes economic problems in a region which can cause a decrease in productivity and income of the community. Thus, the negative impacts that arise can increase the potential for fiscal illusions. The unemployment rate is an indicator that is usually used to analyze the health of the regional economy. The higher unemployment rate can cause a lack of community income (Utari, 2015). The continued impact of this is the diminishing ability of the community to contribute to increasing PAD, in other words the decreasing ability to pay local taxes. The regencies / cities government in South Sumatra Province which has a high unemployment rate will have obstacles in trying to increase PAD. Thus, regions will increasingly depend on and seek to obtain large DAU to help finance regional expenditures that cannot be covered by PAD. The results of the overall testing of this research model support research conducted by B. Dollery \& Worthington (1995); Adi \& Ekaristi (2009); Utari (2015) who successfully detected fiscal illusions. The fiscal illusion that occurred in regencies / cities in South Sumatra Province was caused by the high dependence of regional governments on the DAU provided by the central government. The hope of the central government with the DAU is that regional governments can streamline regional expenditure that is prioritized to increase PAD. However, what happens in regencies / cities in South Sumatra Province is that the utilization of DAU is not optimal for productive programs that can have a significant impact on increasing PAD.

\section{Conclusion}

This research proves that through the Revenue Enhancement approach in the regencies / cities in South Sumatra Province there is no fiscal illusion detected. An increase in regional revenue has an impact on increasing the amount of regional expenditure. The expenditure manipulation approach succeeded in detecting fiscal illusions. Fiscal illusions detected through this approach are characterized by a negative correlation between the KR variable (the relative importance of the DAU to regional expenditure) to the PAD budget. The detected fiscal illusion significantly influenced by the variable ratio of national income given by the central government to regional governments, the relative perceptions of the central government towards regional governments, the relative importance of DAU to regional expenditure, and unemployment. Detection of fiscal illusions through the last approach in this study, namely debt utilization. Test results show no fiscal illusions were detected through this approach. Regencies / cities governments in South Sumatra Province do not utilize the right to excessive local debt to finance regional expenditures. Regencies / cities governments in South Sumatra Province finance regional expenditure through PAD sources and transfer funds obtained from the central government. Further research is suggested to include aspects of local government behavior in allocating sources of income including DAU, determining policies related to regional expenditure and its effectiveness in absorbing DAU and PAD to regional expenditure. And expand the unit of analysis to all local governments in Indonesia, so that research results are easier to generalize in Indonesia. This research is limited to the sample which is only in the regencies / cities in South Sumatra Province in the period 2012 to 2018. So the results of the study cannot be generalized to a wider scope. In addition, this study only uses data that has been documented and published by government agencies and institutions, which causes limited discussion on document data that has been collected in this study beforehand.

\section{References}

Adi, P. H., \& Ekaristi, P. D. (2009). Fenomena Ilusi Fiskal Dalam Kinerja Anggaran Pemerintah Daerah. Jurnal Akuntansi Dan Keuangan Indonesia, 6(1), 1-19.

Armawaddin, M. (2015). Analisis Flypapper Effect Pada Belanja Daerah Kabupaten/Kota Di Sulawesi Tenggara. Jurnal Ekonomi Pembangunan, 16, 13-19.

Barro, R. J. (1974). Are government bonds net wealth?. Journal of Political Economy, 82(6), $1095-1117$.

Bhakti, A. (2013). Deteksi Ilusi Fiskal Kabupaten/Kota di Provinsi Jambi (Pengujian Perilaku Asimetris Pemerintah Daerah dalam Merespon Dana Perimbangan). Jurnal Perspektif Pembiayaan Dan Pembangunan Daerah, 1(2), 71-80.

Dang, T., Nguyen, T., Le, K., \& Pham, T. (2020). The information gap in corporate annual reports: Evidence from Vietnam. Accounting, 6(5), 899-912.

Dollery, B. E., \& Worthington, A. C. (1999). Fiscal illusion at the local level: An empirical test using Australian municipal data. Economic Record, 75(1), 37-48.

Dollery, B., \& Worthington, A. (1995). Federal expenditure and fiscal Illusion: A test of the flypaper hypothesis in Australia. Publius, 25(1), 23-34.

Dude, D. P., Kumenaung, A., \& Rotinsulu, D. (2014). Analisis Kinerja Keuangan dan Fiscal Illusion pada Pemerintah Propinsi Sulawesi Utara Tahun 2003-2012. Jurnal Berkala Ilmiah Efisiensi, 14(2), 29-43.

Dwirandra, I. K. J., Suryanawa, I. K., \& Dwirandra, A. (2017). Fiscal illusion detection and the effect on capital expenditure, fiscal decentralization, economic growth, and human development development Index for district/cities in Bali Province. Research Journal of Finance and Accounting, 8(10), 161-169.

Dyahningtyas, R., Suharsih, S., \& Astuti, S. R. B. (2019). Kinerja Keuangan Daerah Dan Deteksi Ilusi Fiskal Pada Pemerintah Daerah Kabupaten/Kota Provinsi Daerah Istimewa Yogyakarta. Jurnal Ekonomi-Qu, 9(1), 119-130.

Gemmell, N., Morrissey, O., \& Pinar, A. (1999). Fiscal illusion and the demand for government expenditures in the UK. 
European Journal of Political Economy, 15(4), 687-704.

Hammes, D. L., \& Wills, D. T. (1987). Fiscal Illusion and the Grantor Government in Canada. Economic Inquiry, 25(4), 707713.

Hapsoro, D., \& Yoduke, R. (2019). Fiscal Illusion Detection and Their Effect on Economic Growth in Sulawesi. Jurnal Economia, 15(2), 172-188.

Islami, A. Y., Edwin, F., \& Riana, M. (2020). Factors influencing the financial perfornace of south Sumatra province local government for the period 2012-2016. Journal of Critical Reviews, 7(15), 2115-2124.

Kuncoro, H. (2007). Perilaku Asimetris Pemerintah Daerah Kota danKabupaten atas Perubahan Besaran Transfer dari Pemerintah Pusat. The 1 St Accounting Conference Faculty of Economics Universitas Indonesia, November, 1-27.

Logan, R. R. (1986). Fiscal illusion and the grantor government robert. Journal of Political Economy, 94(6), $1304-1318$.

Meilya, R., \& Herwanti, T. (2018). Fiscal illusion and defining factors of capital expenditure (Study on undeveloped areas in west Nusa Tenggara). International Review of Management and Marketing, 8(1), 98-106.

Nugroho, M. R. (2017). Flypaper Effect of Regional Expenditures in Yogyakarta. Shirkah: Journal of Economics and Business, 2(3).

Nurhayati, N. (2017). Analisis Deteksi Fiscal illusion dengan Pendekatan Revenue Enchancement Pada Pengelolaan Keuangan Pemerintah Daerah (Studi Kasus Pada Pemerintah Kabupaten/Kota di Wilayah III Cirebon). Jurnal Riset Keuangan Dan Akuntansi, 3(2), 109-119.

Pratami, A. A. P. N. I., \& Dwirandra, A. A. N. B. (2017). Pengaruh PAD, Dana Perimbangan, LPDS, dan PDRB pada Belanja Daerah serta Deteksi Ilusi Fiskal. E-Jurnal Akuntansi Universitas Udayana, 18(2), 1141-1170.

Puviani, A. (1976). Teoria della illusione finanziaria (F. Volpi (ed.); Edizione e). Catia righi.

Rusydi, B. U. (2015). Analisis Determinan Kinerja Keuangan Pemerintah Daerah dan Deteksi Ilusi Fiskal (Studi Kasus Provinsi di Indonesia Tahun 2005-2008). Iqtisaduna, 1(2), 116-129.

Salawali, W. A., Kindangen, P., \& Lapian, A. C. H. (2016). Flypaper Effect pada Dana Alokasi Umum (DAU) Dan Pendapatan Asli Daerah (PAD) serta Pengaruhnya terhadap Belanja Daerah Kabupaten/Kota di Sulawesi Tengah. Jurnal Pembangunan dan Keuangan Daerah, 18(2).

Susilawati, D., Kusumastuti Wardana, L., \& Fajar Rahmawati, I. (2018). Menilai Kinerja Keuangan dengan Analisis Rasio Keuangan: Studi Kasus BKAD Sleman. Jurnal Akuntansi Terapan Indonesia, 1(2), 91-98.

Tasri, A. (2018). The flypaper effect phenomenon: Evidence from Indonesia. European Journal of Engineering and Formal Sciences, 2(1), 20.

Turnbull, G. K. (1992). Fiscal illusion, uncertainty, and the flypaper effect. Journal of Public Economics, 48(2), $207-223$.

Utari, T. (2015). ANalisis Ilusi Fiskal dalam Kinerja Anggaran Pemerintah Daerah di Provinsi Se-Indonesia (Issue 13919016). Universitas Islam Indonesia.

Worthington, A. C., \& Dollery, B. E. (1999). Fiscal illusion and the Australian local government grants process: How sticky is the flypaper effect?. Public Choice, 1-13. doi: 10.1023/A:1018329802757

Yoduke, R. (2018). Deteksi Ilusi Fiskal: Flypaper Effect dan Ilusi Utang pada Belanja Daerah serta Pengaruhnya terhadap Pertumbuhan Ekonomi pada Kabupaten/Kota di Sulawesi (Tesis). Program Pascasarjana STIE Yayasan Keluarga Pahlawan Negara.

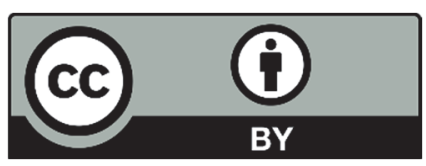

(C) 2020 by the authors; licensee Growing Science, Canada. This is an open access article distributed under the terms and conditions of the Creative Commons Attribution (CC-BY) license (http://creativecommons.org/licenses/by/4.0/). 